Article Type: Commentary

NOTES

Ref 1: [add details at production]

COMMENTARY

$\mathrm{JP}$

23 November 2017

Ms. No. 17/874-Commentary A

\title{
Wet work and healthcare workers: use of hand disinfectants not associated with self-reported eczema
}

DOI: $\mathrm{xx}$ [add details at production]

Linked Article: Hamnerius et al. Br J Dermatol 2017; xxx:xxx-xxx. [add details at production]

T. Keegel $1^{1,2}$ and R.L. Nixon ${ }^{3,4}$

${ }^{1}$ School of Psychology and Public Health, La Trobe University, Melbourne, Australia

${ }^{2}$ Monash Centre for Occupational and Environmental Health, Melbourne, Australia

${ }^{3}$ Occupational Dermatology Research and Education Centre, Skin and Cancer Foundation, Carlton, Australia

${ }^{4}$ Department of Medicine, St Vincent's Hospital, University of Melbourne, Melbourne, Australia

\section{Correspondence}

E-mail: tessa.keegel@monash.edu,t.keegel@latrobe.edu.au

http://orcid.org/0000-0003-2909-9975 (T.K.)

\section{Funding sources}

No external funding.

\section{Conflicts of interest}

None to declare.

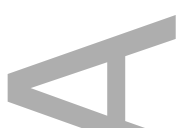

In this issue of the $B J D$, Hamnerius et al. ${ }^{1}$ report the findings from a large cross-sectional study of wet work exposure and hand eczema among Swedish healthcare workers. The

This is the author manuscript accepted for publication and has undergone full peer review but has not been through the copyediting, typesetting, pagination and proofreading process, which may lead to differences between this version and the Version of Record. Please cite this article as doi: 10.1111/bjd.16166 
study found a 1-year prevalence rate of $21 \%$ for self-reported hand eczema among this group of healthcare workers. While this prevalence rate was higher than the rate reported for the general Swedish population (9.4\%), it is in the range of studies of Danish healthcare workers, ${ }^{2,3}$ but is increased compared with a Dutch study which found a 1-year prevalence rate of $12 \% .{ }^{4}$ Despite differences with these prevalence rates, all of the studies indicate that wet work remains an exposure of concern for healthcare workers.

Using a web-based questionnaire, Hamnerius et al. ${ }^{1}$ conducted a survey of all hospital employees in Southern Sweden. Study participants provided information on the use of hand disinfectants and hand washing with soap and water as well as the use of disposable gloves. Information was also collected on demographic factors, as well as wet work exposure outside the workplace. The authors also considered other potential confounding factors such as obesity, smoking, stress and atopic dermatitis. The authors provide anecdotal information that compared with 10-15 years ago, there is a 14-15-fold increase in the purchasing of nonsterile disposable rubber gloves.

The current study suggests that there is a dose-dependent association between the use of disposable gloves, as well as washing the hands with soap and water, and self-reported hand eczema in healthcare workers. However, of importance, there is not a dose-dependent relationship between the use of hand disinfectants and hand eczema.

Of interest, Hamnerius et al. ${ }^{1}$ found a positive correlation between frequent hand washing and the use of alcohol hand rubs, a finding that has been observed previously in a study of Australian healthcare workers. ${ }^{5}$ This leads to the question of whether the message about the use of alcohol hand rubs as a substitution measure for washing the hands with soap and water, rather than as an additional measure in a hand hygiene regime, needs to be communicated more effectively to healthcare workers.

This study needs to be read in the context of an increasing number of hand hygiene campaigns conducted in an effort to limit the spread of hospital infections, not all of which have been evaluated. ${ }^{6}$ In 2015 Stocks et al. alerted us to higher than expected rates of irritant contact dermatitis among healthcare workers, associated with increased efforts to prevent healthcare-associated infections through programmes such as the U.K. 'Cleanyourhands' campaign. ${ }^{7}$ This has prompted calls for the uptake of strategies to protect healthcare workers from developing irritant contact dermatitis, such as the substitution of washing hands with soap and water, with the use of alcohol hand disinfectants, for hands that are not visibly soiled. It would seem reasonable to combine education regarding hand hygiene with advice concerning skin care. ${ }^{8,9}$ 


\section{References}

1 Hamnerius N, Svedman C, Bergendorff O et al. Wet work exposure and hand eczema among healthcare workers - a cross-sectional study. Br J Dermatol (in press) [add details at production]

2 Ibler KS, Jemec GB, Flyvholm MA et al. Hand eczema: prevalence and risk factors of hand eczema in a population of 2274 healthcare workers. Contact Dermatitis 2012; 67:200-7.

3 Flyvholm MA, Bach B, Rose M, Jepsen KF. Self-reported hand eczema in a hospital population. Contact Dermatitis 2007; 57:110-15.

4 van der Meer EW, Boot CR, van der Gulden JW et al. Hand eczema among healthcare professionals in the Netherlands: prevalence, absenteeism, and presenteeism. Contact Dermatitis 2013; 69:164-71.

5 MacFarlane E, LaMontagne AD, Driscoll T et al. Use of antiseptic hand rubs in the health and community services industry: an Australian population-based survey. Contact Dermatitis 2015; 73:157-62.

6 Latham JR, Magiorakos AP, Monnet DL et al. The role and utilisation of public health evaluations in Europe: a case study of national hand hygiene campaigns. BMC Public Health 2014; 14:131.

7 Stocks SJ, McNamee R, Turner S et al. The impact of national-level interventions to improve hygiene on the incidence of irritant contact dermatitis in healthcare workers: changes in incidence from 1996 to 2012 and interrupted times series analysis. $\mathrm{Br} \mathrm{J}$ Dermatol 2015; 173:165-71.

8 Ibler KS, Jemec GB, Diepgen TL et al. Skin care education and individual counselling versus treatment as usual in healthcare workers with hand eczema: randomised clinical trial. BMJ 2012; 345:e7822.

9 Higgins CL, Palmer AM, Cahill JL, Nixon RL. Occupational skin disease among Australian healthcare workers: a retrospective analysis from an occupational dermatology clinic, 1993-2014. Contact Dermatitis 2016; 75:213-22. 


\section{University Library}

\section{- M M N E R VA A gateway to Melbourne's research publications}

Minerva Access is the Institutional Repository of The University of Melbourne

Author/s:

Keegel, T;Nixon, RL

Title:

Wet work and healthcare workers: use of hand disinfectants not associated with selfreported eczema

Date:

2018-02-01

Citation:

Keegel, T. \& Nixon, R. L. (2018). Wet work and healthcare workers: use of hand disinfectants not associated with self-reported eczema. BRITISH JOURNAL OF DERMATOLOGY, 178 (2), pp.324-325. https://doi.org/10.1111/bjd.16166.

Persistent Link:

http://hdl.handle.net/11343/283595 